\title{
EU member state government contribution to alternative methods
}

\author{
Summary \\ Article 47 of the new EU Directive 2010/63/EU on the protection of animals used for scientific purposes \\ requires national governments to contribute to the development and promotion of alternative methods. \\ A recent survey of EU member states found that reported funding of alternative (3Rs) methods totalled \\ $€ 18.7$ million in 2013, provided by only seven countries (Austria, Belgium, Denmark, Finland, Germany, \\ Sweden, and the UK). There were indications that the contributions of some of these countries have \\ increased since the implementation of the new Directive. However, funding of alternatives is between \\ $O$ and $0.036 \%$ of national science $R \& D$ expenditure and nearly half of the countries that responded \\ reported that they do not specifically contribute. Data (and, by assumption, financial contribution) remains \\ unavailable from half of the member states across the EU, regardless of the method of collection.
}

\section{Introduction}

Directive 2010/63/EU on the protection of animals used for scientific purposes entered into force across the EU on January 1, 2013 (EC, 2010). The Directive places duties on member states (MS) related not only to the authorisation of experiments on live animals. According to Article 47 of the Directive (Box 1), national governments should also assist in the advancement of alternative methods to animal testing. They should do this by contributing to the development of alternative methods (Article 47(1)), nominating laboratories to assist in the validation of alternative methods (Article 47(2)), and promoting the use of alternative methods (Article 47(4)).

Article 47(1) does not specify that the contribution to the development of alternative methods must be financial. However, significant contribution usually has some financial element attributable to it. For example, providing expertise to support validation studies can be measured in terms of the cost of the expert's time and travel. Historically, there is a lack of good data on the expenditure on the development of alternatives by European countries. A survey coordinated by Eurogroup for Animals and ECOPA for the years 2006/7 reported an estimated annual funding of $€ 17$ million (Devolder et al. 2008); however data was only available from 14 of the current MS and was estimated in some of these cases. In 2010, the current 27 MS had to report to the European Commission (EC) under the REACH legislation on how much they had invested on alternative methods. Half of all MS could not identify any specific funding and the total estimated funding in 2010 by the remaining 14 MS was just over $€ 8$ million (see EC, 2012). However, this contribution could have been perceived to be in relation to alternatives for chemicals' safety assessment only and not all areas of animal testing.

We were therefore interested in the extent to which MS had considered their role in the contribution to the development, validation, and promotion of alternative methods outlined in Article 47, and whether, as a result of the new Directive, investment in this area was likely to be increased. In June 2013 our members wrote to their national governments to ask four questions:

- How much did the Government fund alternatives (replacements, reduction and refinement methods) in 2010, 2011, and 2012? How much of this funding was directed towards replacement, reduction, and refinement, respectively?

- How much funding has the Government committed to continuing the development and validation of alternative approaches in 2013 and beyond in line with Article 47(1)?

- Has the Government nominated any national laboratories to assist the European Centre for the Validation of Alternative Methods (ECVAM) in the validation of alternative methods (so called NETVAL) (Article 47(2))? If not, why not?

- How does the Government propose promoting alternative methods and disseminating information thereon, within Article 47(4)?

Thirteen of our members wrote to their government department, minister, or asked a parliamentary question. For the remaining MS a letter addressed to the National Contact Point (NCP) (designated in Article 59(2) of the Directive) was sent in English. In

Received January 6, 2014; Epub January 24, 2014; http://dx.doi.org/10.14573/altex.1401061 
November 2013 replies from 18 MS had not yet been received and therefore a reminder email was sent to the NCP. Funding of alternative methods was compared to the national science and technology research and development (R\&D) expenditure for each country for 2011, reported by Eurostat (EU, 2013), as data for 2013 are not yet available.

\section{Article 47 of Directive 2010/63/EU}

1. The Commission and the Member States shall contribute to the development and validation of alternative approaches which could provide the same or higher levels of information as those obtained in procedures using animals, but which do not involve the use of animals or use fewer animals or which entail less painful procedures, and they shall take such other steps as they consider appropriate to encourage research in this field.

2. Member States shall assist the Commission in identifying and nominating suitable specialised and qualified laboratories to carry out such validation studies.

3. After consulting the Member States, the Commission shall set the priorities for those validation studies and allocate the tasks between the laboratories for carrying out those studies.

4. Member States shall, at national level, ensure the promotion of alternative approaches and the dissemination of information thereon.

5. Member States shall nominate a single point of contact to provide advice on the regulatory relevance and suitability of alternative approaches proposed for validation.

6. The Commission shall take appropriate action with a view to obtaining international acceptance of alternative approaches validated in the Union.

\section{Summary of responses}

Responses to the questions were received from only $13 \mathrm{MS}$, out of 26 contacted. Questions directed at the National Contact Point were the least successful method of contact. This is unfortunate since the role of NCPs is to act as a point of contact on the Directive and their details are publicly available on the European Commission website (http://ec.europa.eu/environment/ chemicals/lab_animals/ms_en.htm). The failure of national governments to respond to queries related to the implementation of the Directive made by legitimate stakeholders is of immediate concern. Language barriers could explain the lack of some responses, but not in all cases, since formal requests in the national language even via parliamentarians, were not dealt with by countries such as Italy, Portugal, and France.

Based on our survey, we can identify that only a total of $€$ 18.7 million has been allocated by only seven MS (Austria, Belgium, Denmark, Finland, Germany, Sweden, and the UK), see Table 1. Five MS (Czech Republic, Ireland, Latvia, Luxembourg, and Spain) have not allocated any funds for 2013 and did not in previous years; the competent authority for Slovakia did not know if funding had been allocated. None of the replies broke down the amounts by replacement, reduction, and refinement methods, as requested.

Out of those responding with allocation, the funding of alternatives was between 0 to $0.036 \%$ of national $R \& D$ science expenditure in 2011, with the UK providing the most funds, both in real terms and as a proportion of their science R\&D expenditure (over $€ 11$ million, see Tab. 1). Funding appears to have increased significantly on previous years for four of the seven countries: Austria, Denmark, Finland, and the UK. However, funding from the remaining three contributing countries and the five non-contributing countries appears to be very similar to 2010 .

Our data is not directly comparable to the Devolder et al. (2008) survey, since this asked an open-ended question about funding, included non-EU countries, did not provide absolute figures by country, and included estimates from other sources, including industry contributions, even where the government said it did not provide specific funds. Since the specific government funding pledged for 2013 from the seven MS reported in our survey is in excess of the Devolder et al. estimate, we can however assume that funding overall has increased, although not significantly.

At least 15 laboratories have been nominated by seven MS according to the replies we received. However, we believe the figure is higher, as in July 2013 ECVAM accepted 13 laboratories from those nominated to join the NETVAL (see http://ihcp. jrc.ec.europa.eu/our_labs/eurl-ecvam/eu-netval/eurl-ecvam-appoints-members-of-eu-netval). Some governments that were not specifically funding alternatives, such as Spain, Latvia, and the Czech Republic, nominated laboratories, whereas some pledging funds reportedly did not (Austria, Denmark and the UK).

Only six MS provided a reasonable response to how they were going to 'promote the use of alternative methods' (Article 47 (4)) above standard requirements within the Directive, such as ethical committees, animal welfare bodies, and national contact points. Finland, Germany, and UK already have national centres for the $3 \mathrm{Rs}$ and were planning to delegate this responsibility to them. Denmark and Spain indicated that new centres or networks would be created for this purpose. Austria reported their support for the EUSAAT annual conference and other educational seminars. Neither Malta nor Luxembourg currently have animal testing facilities registered under the new Directive. Their negative responses to the funding and promotion of alternatives appeared to reflect this fact; nonetheless there is no reason why such countries could not also promote alternative methods.

There are positive signs that there has been an increase in promotion and funding of alternative methods in some EU countries. Nonetheless, funding appears to be at very low levels and is less than $0.05 \%$ of national science research and development budgets. In addition, in keeping with previous surveys, it appears that engagement in alternatives (and in the requirements of Article 47 specifically) remains restricted to a familiar group of MS, less than a third of the total in the EU. Even then, there is inconsistency in the extent of their investment. For example, the $\mathrm{UK}$ is the largest financial contributor but it did not nominate 
Tab. 1: Summary of the responses from 27 Member States in 2013 on their efforts to fund and promote alternatives to animal testing according to Article 47 of Directive 2010/63/EU

\begin{tabular}{|c|c|c|c|c|c|c|c|}
\hline $\begin{array}{l}\text { Member } \\
\text { State }\end{array}$ & $\begin{array}{l}\text { Method of } \\
\text { contact }\end{array}$ & $\begin{array}{l}\text { Previous } \\
\text { funding, } \\
€\end{array}$ & $\begin{array}{l}\text { Funding } \\
\text { for } 2013 \\
\text { (Article 47(1)), } \\
€\end{array}$ & $\begin{array}{l}\text { Nomination of } \\
\text { laboratories } \\
\text { (Article } 47(2) \text { ) }\end{array}$ & $\begin{array}{l}\text { Promotion of } \\
\text { alternatives } \\
\text { (Article 47(4)) }\end{array}$ & $\begin{array}{l}\text { Science R\&D } \\
\text { expenditure } \\
2011 \text {, million } \\
€(E U, 2013)\end{array}$ & $\begin{array}{l}\text { \% investment } \\
\text { in alternatives } \\
\text { out of } \\
\text { science R\&D } \\
\text { expenditure }\end{array}$ \\
\hline AT & $\begin{array}{l}\text { Letter to } \\
\text { minister }\end{array}$ & $\begin{array}{r}74,700(2010) \\
1,506(2011) \\
85,988(2012)\end{array}$ & 290,000 & None as yet & $\begin{array}{r}\text { Support for EUSAAT } \\
\text { Linz conference, } \\
\text { seminars for regulators } \\
\text { of animal experiments }\end{array}$ & 8,263 & 0.0035 \\
\hline BE & $\begin{array}{l}\text { Letter to } \\
\text { minister }\end{array}$ & $\begin{array}{r}395,497(2010) \\
0(2011) \\
0(2012) \\
\end{array}$ & 155,600 & 4 & $\begin{array}{l}\text { Some oversight of the } \\
\text { animal welfare body } \\
\text { in each establishment }\end{array}$ & 7,556 & 0.0021 \\
\hline$B G$ & Letter to NCP & No reply & & & & 220 & $?$ \\
\hline $\mathrm{CY}$ & Letter to NCP & No reply & & & & 86 & $?$ \\
\hline $\mathrm{CZ}$ & $\begin{array}{l}\text { Letter to } \\
\text { government } \\
\text { department }\end{array}$ & 0 & 0 & Yes, unknown & Created a NCP & 2,875 & 0 \\
\hline DK & $\begin{array}{l}\text { Various } \\
\text { parliamentary } \\
\text { questions }\end{array}$ & 0 & $\begin{array}{r}402,176 \\
(3 \text { million DKK })\end{array}$ & None as yet & $\begin{array}{r}\text { Creation of a new } \\
\text { 3Rs center }\end{array}$ & 7,437 & 0.0054 \\
\hline ET & Letter to NCP & No reply & & & & 379 & $?$ \\
\hline $\mathrm{FI}$ & $\begin{array}{l}\text { Letter to } \\
\text { minister }\end{array}$ & $40,000(2010)$ & \begin{tabular}{r|}
100,000 \\
$40,000(2011)$ \\
$40,000(2012)$ \\
\end{tabular} & 1 & $\begin{array}{l}\text { Plan to promote using } \\
\text { the Finnish Centre for } \\
\text { Alternative Methods }\end{array}$ & 7,164 & 0.0014 \\
\hline FR & $\begin{array}{l}\text { Letter to } \\
\text { minister }\end{array}$ & No reply & & & & 44,922 & $?$ \\
\hline $\mathrm{DE}$ & Letter to NCP & $\begin{array}{r}5,015,000 \\
\text { (annually from } \\
\text { various } \\
\text { ministries) }\end{array}$ & $5,015,000$ & 3 & $\begin{array}{r}\text { Via ZEBET (German } \\
\text { centre for 3Rs), also } \\
\text { AnimALT-ZEBET data- } \\
\text { base on alternatives }\end{array}$ & 73,692 & 0.0068 \\
\hline EL & Letter to NCP & No reply & & & & 1,342 & $?$ \\
\hline $\mathrm{HU}$ & Letter to NCP & No reply & & & & 1,205 & $?$ \\
\hline IE & $\begin{array}{l}\text { Parliamentary } \\
\text { question }\end{array}$ & 0 & 0 & $\begin{array}{r}\text { Being } \\
\text { considered }\end{array}$ & Being considered & 2,741 & 0 \\
\hline IT & $\begin{array}{l}\text { Parliamentary } \\
\text { question }\end{array}$ & No reply & & & & 19,756 & $?$ \\
\hline LV & Letter to NCP & 0 & 0 & 3 & Still being considered & 141 & 0 \\
\hline LT & Letter to NCP & No reply & & & & 282 & $?$ \\
\hline LU & Letter to NCP & 0 & 0 & None & $\begin{array}{r}\text { No animal testing } \\
\text { facilities }\end{array}$ & 608 & 0 \\
\hline MT & Letter to NCP & No reply & & & & 47 & $?$ \\
\hline NL & $\begin{array}{l}\text { Not contacted, } \\
\text { not transposed }\end{array}$ & $\mathrm{n} / \mathrm{a}$ & & & & 12,292 & $?$ \\
\hline PL & Letter to NCP & No reply & & & & 2,836 & $?$ \\
\hline PT & $\begin{array}{l}\text { Parliamentary } \\
\text { question }\end{array}$ & No reply & & & & 2,557 & $?$ \\
\hline RO & Letter to NCP & No reply & & & & 657 & $?$ \\
\hline SK & Letter to NCP & No reply & & & & 468 & $?$ \\
\hline SL & $\begin{array}{l}\text { Letter to } \\
\text { government } \\
\text { department }\end{array}$ & Do not know & Do not know & Do not know & Do not know & 894 & $?$ \\
\hline
\end{tabular}




\begin{tabular}{|c|c|c|c|c|c|c|c|}
\hline $\begin{array}{l}\text { Member } \\
\text { State }\end{array}$ & $\begin{array}{l}\text { Method of } \\
\text { contact }\end{array}$ & $\begin{array}{l}\text { Previous } \\
\text { funding, } \\
€\end{array}$ & $\begin{array}{l}\text { Funding } \\
\text { for } 2013 \\
\text { (Article 47(1)), } \\
€\end{array}$ & $\begin{array}{l}\text { Nomination of } \\
\text { laboratories } \\
\text { (Article } 47(2) \text { ) }\end{array}$ & $\begin{array}{l}\text { Promotion of } \\
\text { alternatives } \\
\text { (Article } 47(4) \text { ) }\end{array}$ & $\begin{array}{l}\text { Science R\&D } \\
\text { expenditure } \\
2011 \text {, million } \\
€(E U, 2013)\end{array}$ & $\begin{array}{l}\text { \% investment } \\
\text { in alternatives } \\
\text { out of } \\
\text { science R\&D } \\
\text { expenditure }\end{array}$ \\
\hline SP & $\begin{array}{l}\text { Letter to } \\
\text { minister }\end{array}$ & $\begin{array}{l}\text { Not possible } \\
\text { to determine }\end{array}$ & $\begin{array}{r}\text { No specific } \\
\text { budget }\end{array}$ & 7 & $\begin{array}{r}\text { Cooperation agreement } \\
\text { with the Spanish } \\
\text { network for the develop- } \\
\text { ment of alternative } \\
\text { methods (REMA), co- } \\
\text { ordination with } \\
\text { autonomous regions, } \\
\text { educational course } \\
\text { planned }\end{array}$ & 14,184 & 0 \\
\hline SE & $\begin{array}{l}\text { Letter to } \\
\text { government } \\
\text { department }\end{array}$ & $\begin{array}{r}13 \text { million SEK } \\
\text { per year }\end{array}$ & $\begin{array}{r}1,689,762 \\
(15 \text { million } \\
\text { SEK) }\end{array}$ & Several & $\begin{array}{r}\text { A June } 2012 \text { report on } \\
\text { how the government can } \\
\text { do this is still being } \\
\text { considered }\end{array}$ & 13,078 & 0.013 \\
\hline UK & $\begin{array}{l}\text { Parliamentary } \\
\text { question }\end{array}$ & $\begin{array}{r}8,635,000 \mathrm{GBP} \\
(2010) \\
8,100,00 \mathrm{GBP} \\
(2011) \\
8,104,000 \mathrm{GBP} \\
(2012) \\
\text { (across various } \\
\text { ministries) }\end{array}$ & $\begin{array}{r}11,071,467 \\
(9,215,000 \\
\text { GBP })\end{array}$ & None as yet & $\begin{array}{r}\text { via the National Centre } \\
\text { for the 3Rs, inspectors } \\
\text { promote 3Rs within } \\
\text { institutions and } \\
\text { elsewhere, government } \\
\text { commitment to reduce } \\
\text { numbers (strategy not } \\
\text { released yet) }\end{array}$ & 30,993 & 0.036 \\
\hline TOTAL & & 13 replies & $18,724,005$ & $15+$ & & & \\
\hline
\end{tabular}

any potential NETVAL laboratories; Spain nominated seven laboratories but does not specifically contribute any government funds to alternatives. Within those countries contributing funds there is a 25 -fold difference in the proportion of science $R \& D$ funding that goes to alternative method development. Large, older EU states such as Italy and France failed to even respond to the survey and concerns remain that historically their investment is not proportionately as high as that of other, smaller MS. There continue to be problems with acquiring information from the newer or more Eastern MS.

Those working in the field of alternatives to animal testing should remain concerned about this apparent lack of commitment across the EU to the development and promotion of alternative methods. It is important that all EU MS are aware that they have a responsibility under Article 47 to contribute. We encourage the European Commission and key individuals within MS to ensure that by the end of 2014 all MS have indicated publicly how they intend to satisfy Article 47. Only when we have a clear answer can we then assess whether this contribution is appropriate, proportionate and, importantly, adequate.

Replies from MS are available on request.

\section{References}

Devolder, T., Reid, K., Rogiers, V., et al. (2008). Research expenditure for 3R alternatives: A review of national public funding programmes in European countries. ALTEX 25, 233-242. http://www.altex.ch/All-issues/Issue.50.html?iid=101\&aid=7 (accessed 06.02.2014)

EC - European Commission (2012). Member state reports on the operation of REACH (Art.117) submitted on 1 June 2010. http://ec.europa.eu/environment/chemicals/reach/art_117_ en.htm

EU - European Union (2010). Directive 2010/63/EU of the European Parliament and of the Council of 22 September 2010 on the protection of animals used for scientific purposes. Off J Eur Union L276, 33-79.

EU (2013). Eurostat pocket book: Science, technology and innovation in Europe, 2013 edition. Luxembourg: Publications Office of the European Union.

Katy Taylor, $\mathrm{PhD}$

European Coalition to End Animal Experiments (ECEAE)

16 a Crane Grove

London N7 8NN

UK

e-mail: katy.taylor@buav.org 